Pomáhajúce profesie, roč. 2, č. 1, 2019, 53-63

\title{
VZŤAH OSOBNOSTI A KARIÉROVÝCH ZÁUJMOV U MANAŽÉROV
}

\author{
Miriama Hudáková ${ }^{1}$, Tímea Mráziková ${ }^{2}$ \\ 1 Ústav aplikovanej psychológie FSVaZ UKF Nitra, \\ ${ }^{2}$ Katedra psychologických vied FSVaZ UKF Nitra, \\ mhudakova2@ukf.sk
}

\begin{abstract}
Abstrakt: Ciel'om štúdie bolo skúmanie vzt'ahu medzi Hollandovou (1997) teóriou kariérových záujmov a pät'faktorovým modelom osobnosti (Costa, McCrae, 1992) u manažérov. Výskumnú vzorku tvorilo 79 manažérov (47 mužov, 32 žien) s priemerným vekom $M=43,01 \quad(S D=9,25)$. Na meranie pät'faktorovej štruktúry osobnosti bol použitý dotazník mini-IPIP (Mini-International Personality Item Pool). Kariérové záujmy boli zist’ované prostredníctvom Dotazníka štruktúry všeobecných záujmov (DŠVZ). Zistili sme, že tri osobnostné dimenzie korelujú s kariérovými záujmami. Niektoré vzt’ahy kariérových záujmov a dimenzií osobnosti môžu byt' u manažérov špecifické.
\end{abstract}

Kl'účové slová: kariérové záujmy, osobnost', manažéri

\section{1 ÚVOD}

Myšlienka, že kariérové záujmy sú zásadným spôsobom spojené so širšou skupinou dispozičných konštruktov inak identifikovaných ako osobnostné premenné je opakujúcou sa témou v literatúre zameranej na kariérové záujmy (Hogan, Blake, 1999). Pátranie po zhode medzi osobnost'ou a kariérovými záujmami sa začalo od 80. rokov minulého storočia a je to téma, ktorá aj v súčasnosti zaujíma množstvo bádatel'ov. Väčšina výskumov venujúcich sa tejto problematike (napr. Costa, McCrae, Holland, 1984; Holland, Johnstun, Asama, 1994; Tokar, Vaux, Swanson, 1995; Tokar, Swanson, 1995; Schinka, Dye, and Curtiss, 1997; Carless, 1999 a iné) však skúmala uvedený vzt'ah na pomerne všeobecnej vzorke zamestnaných dospelých, resp. na vzorke vysokoškolských študentov. V predkladanej štúdii sme sa rozhodli skúmat' vzt'ah osobnosti a záujmov na špecifickej vzorke manažérov. Manažér v dnešnej dobe nie je len osoba s predpokladmi na vedenie, ale do popredia sa dostávajú jeho črty osobnosti z najširšieho uhla pohl'adu (Cejthamr, Dědina, 2010). Rozmanitost' a náročnost' činností, úloh a rolí manažérskej profesie kladie na osobnost' manažéra vysoké nároky (Míka, 2006). Osobnost' manažéra predstavuje súhrn jeho psychických a fyzických predpokladov k zastávaniu istého druhu činností. Čím lepší je súbor požadovaných vlastností, tým rastie jeho schopnost' úspešne vykonávat' tomuto súboru primeranú činnost' (Stýblo, 1993). Osobnost' je teda dôležitým aspektom pre výkon manažérskej profesie ale tiež pre výber tejto profesijnej orientácie. Osobnostné vlastnosti sú prediktorom, ktorý berieme do úvahy pri predikcii v oblasti pracovného uplatnenia, výkonnosti a predovšetkým pri správnom pracovnom zaradení človeka (Vendel, 2008). Podobne aj záujmy predikujú správanie a dosahovanie ciel'ov v pracovných podmienkach (Rounds, Su, 2014; Bergmann, Eder, 2011) a sú silným motivačným faktorom kariérového vývinu a kariérovej vol'by (Lepeňová, Hargašová, 2012). Rozhodujú nie len o povolaní, ktoré človek vykonáva, ale aj o spokojnosti v ňom (Vendel, 2008). Vychádzajúc z uvedeného považujeme obe zmienené premenné, osobnost’ aj záujmy, za významné v kontexte manažérskej profesie resp. kariéry. Vendel (2008) taktiež poukazuje na to, že osobnost' a záujmy patria medzi základné faktory zohrávajúce rolu v kariérovom vývine človeka. Preto si za ciel’ štúdie pokladáme skúmanie súvislosti medzi osobnost'ou v intenciách teórie Big Five a záujmami podl'a Hollandovej teórie na výskumnej vzorke manažérov. 


\subsection{Kariérové záujmy podl’a Hollandovej teórie}

Záujmy predstavujú špecifickú orientáciu osobnosti a koncentráciu pozornosti na danú vec alebo aktivitu (Lepeňová, Hargašová, 2012). Energizujú a smerujú aktivitu k dosiahnutiu a zachovaniu prostredia, ktoré je najvhodnejšie k napíňaniu jednotlivcových potrieb (Armstrong, Su, Rounds, 2011). Za najrozšírenejšiu taxonómiu kariérových záujmov so silnou empirickou podporou sa považuje Hollandova teória (Pässler, Beinicke, Hell, 2015), z ktorej v štúdii vychádzame. Bola vyvinutá s ciel'om popísat', pochopit' a predikovat' kariérovú vol'bu, ktorú l'udia uskutočňujú, vrátane výberu odborov štúdia, povolaní a následne pracovných miest (Gottfredson, Johnstun, 2009). Podl'a Hollanda (1997) patrí väčšina l'udí k jednému zo šiestich osobnostných typov predstavujúcich osobnú orientáciu alebo životný štýl, teda k typu: prakticko-technickému, intelektuálno-vedeckému, umelecko-jazykovému, sociálnemu, podnikatel'skému a organizačnoriadiacemu. Holland (1997) charakterizuje jednotlivé záujmové typy nasledovne:

L’udia prakticko-technického typu $(R)$ majú radi činnosti vyžadujúce silu, koordináciu pohybov a zručnosti. Je pre nich typický sklon k práci s materiálom, používanie nástrojov a zariadení. Intelektuálno-vedecké typy (I) majú radi rébusy a zložité matematické a vedecké problémy vyžadujúce premýšlanie. S obl'ubou sa učia a dávajú prednost' poznávacím a vedeckým aktivitám. L’udia umelecko-jazykového typu (A) uprednostňujú príležitosti, ktoré im umožnia umelecky sa prejavit' - hudbou, výtvarným a pohybovým umením alebo literárnou tvorbou. Jednotvárna práca ich nudí. Snažia sa o originalitu. Sociálne typy $(S)$ dávajú prednost' spoločenským typom činnosti, pri ktorých sa môžu venovat' iným l'ud'om, a to formou výchovy, vyučovania alebo pomoci človeku. Jednotlivci podnikatel'ského typu (E) sú radi v styku s inými l'ud'mi a hovoria s nimi o obchodných témach, chcú ich presvedčit' alebo riadit'. V styku s inými sa presadzujú, sú populárni a snažia sa zaujat' vedúce miesta. Organizačno-riadiace typy $(C)$ uprednostňujú presne určené zaobchádzanie s údajmi. Vážia si peniaze, spol'ahlivost' a schopnosti pracovat' podl'a pravidiel a nariadení.

Porovnaním jednotlivcových charakteristík s každým modelovým typom je možné identifikovat' typ, ktorému sa jednotlivec najviac podobá. Typ s najväčšou mierou podobnosti definuje jednotlivcov záujmový typ (Holland, 1973,1979). Ak sú taktiež zohl'adnené typy s druhou a tret'ou najväčšou mierou podobnosti, je možné popísat' jednotlivcovu záujmovú štruktúru v diferencovanejších pojmoch (Holland, 1973,1979). Holland (1997) pri charakterizovaní jednotlivých záujmových dimenzií uvádza tiež príklady povolaní, ktoré sú typické pre l’udí s touto záujmovou orientáciou. Podl'a Hollandovej teórie manažérske povolania prislúchajú podnikatel'skému záujmovému typu (Mezera, 2005), pričom záujmový typ na druhom a tret’om mieste môže byt' rôzny podl'a ich špecializácie resp. zamerania (napr. manažér cestovného ruchu, manažér auditu a pod.). Každé povolanie totiž môže byt' charakterizované trojmiestnym kódom (napr. ESC) na základe troch najviac preferovaných záujmových dimenzií.

\subsection{Osobnost' v kontexte pät'faktorového modelu Big Five}

O osobnosti človeka hovoríme ako o organizácii jeho duševného života (Boroš, Ondrišková, Živčicová, 1999). Hřebíčková (2011) uvádza, že osobnost' človeka najviac vystihuje pät’faktorový model osobnosti Big Five, ktorý je príkladom dimenzionálneho taxonomického modelu. Pät'faktorový model osobnosti vznikol na základe analýz pojmov pôvodne klasifikovaných z anglických slovníkov a hl'adanie univerzálnych dimenzií vlastností osobnosti bolo založené na lexikálnych štúdiách v rôznych jazykoch (Ruisel, 2008). Model Big Five predstavuje taxonómiu hlavných dimenzií osobnosti, ktorými sú: extraverzia, neurotizmus/emočná stabilita, otvorenost' voči skúsenosti, svedomitost' a prívetivost' (McCrae, John, 1992). Uvádzame stručný popis piatich vel'kých faktorov osobnosti:

Neurotizmus odlišuje jednotlivcov náchylných k psychickému vyčerpaniu a t’ažko zvládajúcich psychickú zátaž od jednotlivcov vyrovnaných a odolných voči psychickému vyčerpaniu. 
Extraverzia zist'uje kvantitu interpersonálnych interakcií, úroveň aktivácie a stimulácie. Otvorenost' voči skúsenosti zist’uje vyhl'adávanie nových skúseností, zážitkov a toleranciu z neznámeho. Svedomitost' zist'uje mieru motivácie a vytrvalosti na ciel' zameraného správania. Odlišuje spol’ahlivých, na seba náročných l’udí od tých, ktorí sú l’ahostajní a nedbalí (Hřebíčková, 2011). Vysoká svedomitost' vedie k vyššej všeobecnej efektívnosti (Ruisel, Halama, 2007). Prívetivost' zist'uje kvalitu interpersonálnej orientácie na kontinuu od súcitenia po nepriatel'skost' v myšlienkach pocitoch i činoch (Hřebíčková, 2011). Model vel'kej pät'ky zachytáva na širokom stupni abstrakcie podobnosti medzi väčšinou existujúcich systémov na popis osobnosti a poskytuje integratívny deskriptívny model pre výskum osobnosti (John, Srivastava, 1999). Podl'a Judgeho et al. (2002) je pät’faktorový model osobnosti vhodný aj na predikovanie úspešného vedenia.

\subsection{Osobnost' a profesia manažéra}

„Manažér je líder, vodca, správca, organizátor, koordinátor, manažér analyzuje informácie, rozhoduje o ciel'och a postupoch, vedie svojich spolupracovníkov, manažér plánuje a organizuje“ (Míka, 2006, s. 131). Na základe uvedenej definície manažérskej profesie a úloh, ktoré táto profesia zahŕňa, môžeme uvažovat' o tom, že manažérske povolanie preferujú l'udia s určitými kariérovými záujmami (ako sme už uviedli, najmä jednotlivci s podnikatel’skými záujmami) a tiež s určitými osobnostnými charakteristikami. Pre zvládanie náročných personálnych problémov je potrebné, aby manažér disponoval určitými schopnost’ami, ktoré pramenia z jeho samotnej osobnosti (Veber et al., 2007). Osobnost’ manažéra je možné priblížit' z hl'adiska piatich dimenzií osobnosti teórie Big Five. Manažéri, ktorí sú menej neurotickí, nemajú tendenciu prežívat' vo vel'kej miere negatívne emócie a tým sú menej pesimistickí a kritickí voči sebe a okoliu. Pozitívnou stránkou neurotických manažérov je ich kritický postoj, ak je potrebné prostredníctvom kritiky zvýšit' výkon zamestnancov a podriadených (Jones, George, Hill, 1998). Čo sa týka extraverzie, tá podl’a výskumu realizovaného Judgem et al. (2002) súvisí s efektivitou manažéra. Prívetivost' je dôležitá pre manažérov, ktorí majú zodpovednost' za rozvíjanie vzt'ahov s ostatnými. Manažéri, ktorí začínajú svoju kariéru, by mali byt' čo najviac otvorení voči novým skúsenostiam, čo prispieva k ich úspechu. Manažéri vyhýbajúci sa otvorenosti sú menej naklonení riskovaniu a sú viac konzervatívni v plánovaní a rozhodovaní. Vzhl'adom na svedomitost' je potrebné aby sa manažér nepohyboval na spodnej hranici rozmedzia pre túto schopnost' (Jones, George, Hill, 1998).

\subsection{Vzt'ah osobnosti a kariérových záujmov u manažérov}

Osobnostné vlastnosti a kariérové záujmy sú dve významné nonkognitívne individuálne odlišné domény v psychológii (Mount et al., 2005). Vzájomne ovplyvňujú profesijné správanie akým je vol'ba povolania, pracovná spokojnost' alebo kariérne zmeny počas celého života (Larson, Rottinghaus, Borgen, 2002). Poprední odborníci v oblasti kariérových záujmov a osobnosti nezávisle od seba vytvorili dominantné modely individuálnych rozdielov, ktorými sa v štúdii zaoberáme: Hollandov (1997) model kariérových záujmov a pät’faktorový model osobnosti „big five“ (Costa, McCrae, 1992). Hollandova teória kariérovej vol'by (1997) na rozdiel od väčšiny prác zaoberajúcich sa kariérovými záujmami explicitne uznáva rolu osobnosti (Costa, McCrae, Holland, 1984). Podl'a Hollanda predstavujú kariérové záujmy dôležitý aspekt alebo formu vyjadrenia osobnosti (Bergmann, Eder, 2011). Autori spomínaných modelov sa prvýkrát zaoberali ich konvergenciou v roku 1984 (Costa, McCrae, Holland, 1984) a zistili ich značné prekrývanie (Larson, Borgen, 2002). Následne bolo uskutočnených osem štúdií skúmajúcich súvislost' medzi pät'faktorovým modelom osobnosti a Hollandovým modelom kariérových záujmov (Gottfredson, Jones, Holland, 1993; Holland, Johnstun, Asama, 1994; Tokar, Swanson, 1995; Tokar, Vaux, Swanson, 1995; DeFruyt, Mervielde, 1997; Schinka, Dye, Curtiss, 1997; Carless, 1999), ktoré zistili relatívne konzistentné a stredne silné vzt’ahy medzi modelmi ale aj ich nezávislost' (Larson, Borgen, 2002). Tieto výskumy boli realizované na vzorke dospelých aj vysokoškolských študentov. 
V predkladanej štúdii sme si stanovili za ciel' skúmat' vzt'ahy medzi osobnost'ou a kariérovými záujmami na výskumnej vzorke manažérov, vzhl'adom $\mathrm{k}$ tomu, že nám nie je známy výskum zaoberajúci sa ich súvislost'ou na takto špecifickej vzorke, u ktorej, ako sme už spomínali, obe premenné zohrávajú významnú rolu. Predpokladáme, že vzt’ahy medzi osobnost'ou a kariérovými záujmami zistené vo vyššie uvedených ôsmich štúdiách a d’alších výskumoch (napr. Larson, Borgen, 2002; Larson, Rottinghaus, Borgen, 2002; Bergmann, Eder, 2011; Hudáková, Sollár, 2018) sa prejavia aj u manažérov. Na základe výsledkov, ktoré sa vo výskumoch ukazujú ako konzistentné, formulujeme tri druhy predpokladov o vzt'ahu kariérových záujmov a dimenzií osobnosti u manažérov, ktorých zhrnutie uvádzame vtab. 1: predpokladaná pozitívna korelácia (+); predpokladaná nulová resp. nízka alebo nevýznamná korelácia (0); predpokladaná negatívna korelácia (-).

Tab. 1 Predpokladané vzt'ahy medzi kariérovými záujmami a pät'faktorovým modelom osobnosti

\begin{tabular}{lllllll}
\hline & $\mathrm{R}$ & $\mathrm{I}$ & $\mathrm{A}$ & $\mathrm{S}$ & $\mathrm{E}$ & $\mathrm{C}$ \\
\hline Neurotizmus & $\mathbf{0}$ & $\mathbf{0}$ & $\mathbf{0}$ & $\mathbf{0}$ & - & $\mathbf{0}$ \\
Extraverzia & $\mathbf{0}$ & $\mathbf{0}$ & $\mathbf{0}$ & + & + & $\mathbf{0}$ \\
Otvorenost' & $\mathbf{0}$ & $\mathbf{+}$ & $\mathbf{+}$ & $\mathbf{0}$ & $\mathbf{0}$ & $\mathbf{0}$ \\
Svedomitost' & $\mathbf{0}$ & $\mathbf{0}$ & $\mathbf{0}$ & $\mathbf{0}$ & $\mathbf{0}$ & $\mathbf{+}$ \\
Prívetivost' & $\mathbf{0}$ & $\mathbf{0}$ & $\mathbf{0}$ & $\mathbf{+}$ & $\mathbf{0}$ & $\mathbf{0}$ \\
\hline
\end{tabular}

Legenda: : $R$ - prakticko-technické záujmy, I - intelektuálno-vedecké záujmy, A - umelecko-jazykové záujmy, $S$ - sociálne záujmy, E- podnikatel'ské záujmy, C - organizačno-riadiace záujmy, (+) predpokladaný pozitívny vzt'ah, (0) predpokladaný nulový vzt'ah; (-) predpokladaný negatívny vzt'ah

\section{METÓDY}

\subsection{Výskumná vzorka}

Výskumnú vzorku tvorilo 79 manažérov (línioví manažéri, strední manažéri aj vrcholoví manažéri) dvoch rôznych organizácií s priemerným vekom 43,01 (SD = 9,25). Z hl'adiska pohlavia výskumná vzorka pozostávala zo 47 mužov a 32 žien. Pri výbere participantov bol použitý príležitostný výber.

\subsection{Meracie nástroje}

Na meranie pät'faktorovej štruktúry osobnosti sme použili dotazník Mini-IPIP (Mini-International Personality Item Pool; Donnelan et al., 2006). Je odvodený z pôvodného IPIP dotazníka, ktorého autorom je Goldberg (1999). Mini-IPIP je 20-položková škála, kde každá z piatich dimenzií osobnosti (otvorenost' ku skúsenosti, extraverzia, prívetivost', svedomitost', neurotizmus) je meraná štyrmi položkami. Každá položka predstavuje výrok popisujúci správanie a participantovou úlohou je označit' na pät'stupňovej škále nakol'ko ho výrok vystihuje (Cooper, Smillie, Corr, 2010).

Kariérové záujmy boli merané Dotazníkom štruktúry všeobecných záujmov (DŠVZ), ktorý predstavuje slovenskú adaptáciu dotazníka Der Allgemeine Interessenstruktur Test od autorov Bergmanna a Edera (1992). Dotazník pozostáva zo 60 položiek, 10 položiek pre každý zo šiestich Hollandových záujmových typov RIASEC. Preferencia určitého typu záujmu sa zist'uje súčtom jednotlivých položiek. Čím vyššie je skóre pre daný záujmový typ, tým je vyššia jeho preferencia. Položkami sú krátke výroky, pri ktorých respondent vyjadruje mieru záujmu od 1=vôbec ma to nezaujíma do 5 =vel'mi ma to zaujíma (Džuka, 1999).

\section{3 Štatistické spracovanie dát}


Štatistické spracovanie dát sme realizovali v programe IBM SPSS Statistics 24.0. Vzt'ahy medzi dimenziami pät'faktorového modelu osobnosti a kariérovými záujmami sme zist'ovali prostredníctvom Pearsonovej súčinovej korelácie vzhl'adom k normálnej distribúcii dát vo výskumnom súbore.

\section{VÝSLEDKY}

Vo výsledkoch uvádzame vybrané deskriptíve charakteristiky Hollandových záujmových typov vo výskumnej vzorke manažérov, korelujeme jednotlivé osobnostné dimenzie s kariérovými záujmami a sumarizujeme potvrdené a nepotvrdené predpoklady o vzt’ahu kariérových záujmov a osobnosti u manažérov.

Tab. 2 Preferencia Hollandových záujmových typov u manažérov

\begin{tabular}{ccc}
\hline Kariérové záujmy & M & SD \\
\hline Prakticko-technické (R) & 26,013 & 7,762 \\
Intelektuálno-vedecké (I) & 30,873 & 7,603 \\
Umelecko-jazykové (A) & 27,000 & 7,105 \\
Sociálne (S) & 30,747 & 6,060 \\
Podnikatel'ské (E) & 31,380 & 7,405 \\
Organizačno-riadiace (C) & 27,620 & 5,781 \\
\hline
\end{tabular}

Legenda: $M$ - priemer, $S D$ - štandardná odchýlka

Graf 1 Preferencia Hollandových záujmových typov u manažérov na základe priemerného skóre

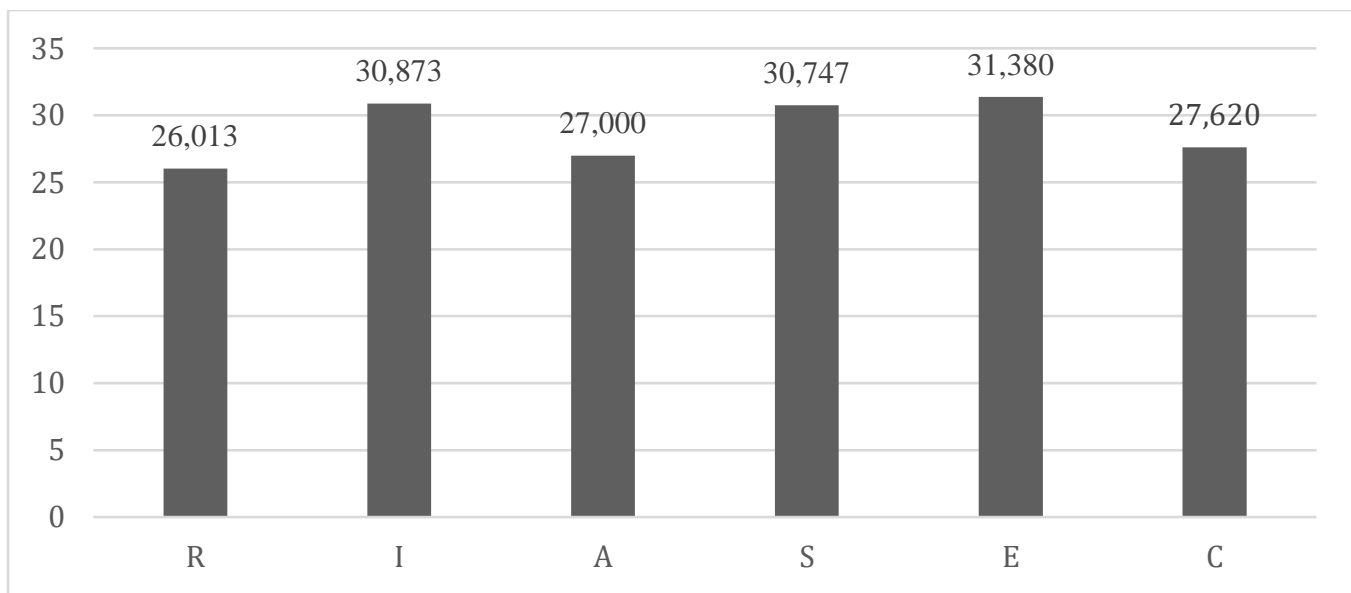

Legenda: R - prakticko-technické záujmy, I - intelektuálno-vedecké záujmy, A-umelecko-jazykové záujmy, $\quad S$ - sociálne záujmy, E-podnikatel'ské záujmy, $C$ - organizačno-riadiace záujmy

Priemerné skóre dosiahnuté v jednotlivých Hollandových záujmových dimenziách poukazuje na to, že manažéri v našej výskumnej vzorke najviac preferujú podnikatel'ské záujmy. Nasledujú intelektuálno-vedecké a sociálne záujmy, ktoré sú u manažérov na druhom a tret’om mieste s takmer rovnakým priemerným skóre. Ďalej sú to organizačno-riadiace záujmy, umeleckojazykové záujmy a najnižšia preferencia sa preukazuje v prípade prakticko-technických záujmov. 
Tab. 3 Korelácie medzi kariérovými záujmami a osobnostnými dimenziami u manažérov

\begin{tabular}{cllllll}
\hline & \multicolumn{1}{c}{$\mathbf{R}$} & \multicolumn{1}{c}{$\mathbf{I}$} & \multicolumn{1}{c}{$\mathbf{A}$} & \multicolumn{1}{c}{$\mathbf{S}$} & \multicolumn{1}{c}{$\mathbf{E}$} & \multicolumn{1}{c}{$\mathbf{C}$} \\
\hline Neurotizmus & $-0,189$ & $-0,171$ & 0,136 & 0,022 & $-0,149$ & $-0,163$ \\
Extraverzia & 0,098 & 0,109 & $-0,034$ & $\mathbf{0 , 3 1 3} * *$ & $\mathbf{0 , 4 3 6 * *}$ & 0,180 \\
Otvorenost' & 0,151 & $\mathbf{0 , 4 0 9 * *}$ & 0,216 & 0,175 & $\mathbf{0 , 2 4 8}$ & 0,067 \\
Svedomitost' & $-0,031$ & $-0,103$ & $-0,112$ & $-0,002$ & $-0,092$ & $-0,002$ \\
Prívetivost' & $\mathbf{- 0 , 2 3 7 *}$ & $-0,108$ & $\mathbf{0 , 3 0 7 * *}$ & $\mathbf{0 , 5 8 7 * *}$ & 0,209 & $-0,069$ \\
\hline
\end{tabular}

Legenda: $R$ - prakticko-technické záujmy, I - intelektuálno-vedecké záujmy, A - umelecko-jazykové záujmy, $S$ - sociálne záujmy, E - podnikatel'ské záujmy, $C$ - organizačno-riadiace záujmy; * $p<0,05 ;{ }^{* *} p<0,01$

Medzi kariérovými záujmami a osobnostnými dimenziami u manažérov sme zistili sedem štatisticky významných vzt’ahov. Preukázali sa dva slabé vzt’ahy, a to negatívny vzt’ah medzi prakticko-technickými záujmami a prívetivost’ou a pozitívny vzt’ah medzi podnikatel'skými záujmami a otvorenost'ou. Ostatné zistené štatisticky významné vzt'ahy boli pozitívne a stredne silné $\mathrm{v}$ rozmedzí od $\mathrm{r}=0,307$ do $\mathrm{r}=0,587$. Na základe zistených korelácií uvádzame $\mathrm{v}$ tab. 4 prehl’ad potvrdených a nepotvrdených predpokladov o vzt’ahu kariérových záujmov a osobnosti.

Tab. 4 Potvrdené a nepotvrdené predpoklady o vzt'ahu kariérových záujmov a osobnostných dimenzií u manažérov

\begin{tabular}{|c|c|c|c|c|c|c|}
\hline & $\mathbf{R}$ & I & A & $\mathbf{S}$ & E & C \\
\hline Neurotizmus & $\checkmark$ & $\checkmark$ & $\checkmark$ & $\checkmark$ & $\mathrm{X}$ & $\checkmark$ \\
\hline Extraverzia & $\checkmark$ & $\checkmark$ & $\checkmark$ & $\checkmark$ & $\checkmark$ & $\checkmark$ \\
\hline Otvorenost' & $\checkmark$ & $\checkmark$ & $\mathrm{X}$ & $\checkmark$ & $\mathrm{X}$ & $\checkmark$ \\
\hline Svedomitost' & $\checkmark$ & $\checkmark$ & $\checkmark$ & $\checkmark$ & $\checkmark$ & $\mathrm{X}$ \\
\hline Prívetivost' & $\mathrm{X}$ & $\checkmark$ & $\mathrm{X}$ & $\checkmark$ & $\checkmark$ & $\checkmark$ \\
\hline
\end{tabular}

\section{DISKUSIA}

Ciel'om štúdie bolo skúmanie súvislosti medzi osobnost'ou vintenciách teórie Big Five a kariérovými záujmami na základe Hollandovej teórie (1997) u manažérov. Teoretický prienik konštruktov vyjadrujú samotní autori teórií, podl’a ktorých Hollandova teória kariérových záujmov explicitne uznáva rolu osobnosti (Costa, McCrae, Holland, 1984) a empiricky bolo prekrývanie konštruktov overované v mnohých štúdiách (Gottfredson, Jones, Holland, 1993; DeFruyt, Mervielde, 1997; Schinka, Dye, Curtis, 1997; Carless, 1999; Larson, Borgen, 2002; Larson, Rottinghaus, Borgen, 2002; Bergmann, Eder, 2011 a d’alší). Prínosom predkladanej štúdie je skúmanie súvislosti zmienených konštruktov na výskumnej vzorke manažérov, s ktorou sme sa v predchádzajúcich výskumoch nestretli. Oba konštrukty, osobnost' aj záujmy, podl'a Vendela (2008) patria medzi základné faktory zohrávajúce rolu v kariérovom vývine človeka, v našom prípade v kariére resp. profesii manažéra, ktorá navyše kladie na osobnost' manažéra vysoké nároky (Míka, 2006). 
Skôr než prejdeme k diskutovaniu zistených vzt’ahov medzi záujmovými dimenziami a osobnostnými vlastnost'ami chceme poukázat’ na preferenciu jednotlivých záujmových dimenzií u manažérov v našej výskumnej vzorke. Na základe priemerného skóre dosiahnutého v záujmových dimenziách sa ukazuje, že u manažérov v našej výskumnej vzorke sú najviac zastúpené podnikatel'ské záujmy, čo je v súlade s Hollandovou (1997) charakteristikou jednotlivcov podnikatel'ského typu, ktorí si podl'a Džuku (1999) vyberajú povolania, v ktorých môžu dosiahnut' zisk vd’aka svojim vodcovským a presvedčovacím schopnostiam, napr. samostatné podnikanie alebo manažérske povolania. $Z$ uvedeného je zrejmé, že manažéri by mali preferovat' práve podnikatel'ský záujmový typ, čo sa preukázalo aj v našich výsledkoch. Ak sa zohl'adňuje záujmový typ na druhom a tret'om mieste, môže byt' každé povolanie charakterizované trojmiestnym kódom (napr. EIC) na základe troch najviac preferovaných záujmových dimenzií. U manažérov v našej výskumnej vzorke boli na druhom mieste zastúpené intelektuálno-vedecké záujmy a na tret'om mieste sociálne záujmy, pričom oba záujmové typy dosahovali takmer rovnaké priemerné skóre. Ďalej nasledovali organizačno-riadiace záujmy a umelecko-jazykové záujmy. Najmenej preferovaným záujmovým typom u manažérov bol prakticko-technický typ charakterizovaný tendenciou zameriavat' sa na konkrétne realizácie a aktivity vyžadujúce dobré motorické zručnosti a koordináciu pohybov (Holland, 1997). Ako ukazuje priemerné skóre, manažéri v našom výskume majú o takýto typ aktivít najmenší záujem.

Pri skúmaní súvislosti medzi osobnost’ou a kariérovými záujmami u manažérov sme zistili 7 štatisticky významných vzt’ahov. Vzt’ahy sa teda preukázali len medzi niektorými osobnostnými vlastnost’ami a určitými kariérovými záujmami, čo je v súlade s našimi predpokladmi aj tvrdením Larsonovej, Rottinghausa a Borgena (2002). Autori tvrdia, že konštrukt kariérových záujmov a pät'faktorový model osobnosti nepochybne navzájom dôležitým spôsobom súvisia, ale nie univerzálne. Určité kariérové záujmy a dimenzie vel'kej pät'ky spolu podstatne súvisia, pokým d’alšie súvisia málo alebo vôbec. Preto sme aj my predpokladali medzi niektorými osobnostnými vlastnost'ami a kariérovými záujmami súvislost' a medzi niektorými nezávislost', čo naše výsledky podporujú.

Predpokladali sme však aj to, že každá osobnostná dimenzia bude vo vzt'ahu s aspoň jedným kariérovým záujmom, čo sa nám nepotvrdilo. Zistili sme, že dve osobnostné dimenzie, neurotizmus a svedomitost', nie sú vo vzt'ahu so žiadnym kariérovým záujmom. Pri neurotizme sme predpokladali negatívny vzt’ah s podnikatel'skými záujmami na základe predošlých výskumov (napr. Bergmann, Eder, 2011; Larson, Rottinghaus, Borgen, 2002; Hudáková, Sollár, 2018). Tokar a Swanson (1995) zistili vzt’ah medzi neurotizmom a podnikatel'skými záujmami len u žien a nie u mužov, čo by mohlo byt' vysvetlením nášho výsledku. Na druhej strane, vo výskume Bergmanna a Edera (2011) a Larsonovej, Rottinghausa a Borgena (2002) sa preukázal tento vzt'ah u oboch pohlaví. Ako pravdepodobnejšie sa tak javí vysvetlenie, že vzt’ah medzi neurotizmom a podnikatel'skými záujmami sa mohol prejavit’ na úrovni faciet. Každá osobnostná dimenzia je totiž tvorená šiestimi facetami. Naše výsledky nesvedčia o štatisticky významnom vzt'ahu medzi neurotizmom a podnikatel'skými záujmami, avšak ukazuje sa aspoň predpokladaný negatívny smer vzt’ahu, ktorý by sa potenciálne mohol preukázat' ako silnejší a štatisticky významný na úrovni faciet. Larsonová a Borgen (2002) uvádzajú, že skúmaním vzt’ahu kariérových záujmov a osobnosti na špecifickej úrovni faciet môžeme získat' silnejšie korelácie ako tie, ktoré boli zistené na všeobecnej úrovni osobnostných dimenzií. Vo výskume Hudákovej a Sollára (2018) sa tiež niekol'ko vzt'ahov medzi osobnost'ou a kariérovými záujmami objavilo len na úrovni faciet.

Pri d'alšej osobnostnej dimenzii, extraverzii, sa nám potvrdili obidva predpokladané vzt'ahy - vzt'ah so sociálnymi aj podnikatel'skými záujmami. Výsledok o vzt’ahu extraverzie s kariérovými záujmami u manažérov je v súlade s predchádzajúcimi výskumami na nešpecifikovanej vzorke 
študentov alebo dospelých (napr. Costa, McCrae, Holland, 1984; Bergmann, Eder, 2011; Larson, Borgen, 2002; Larson, Rottinghaus, Borgen, 2002 a iné).

Čo sa týka dimenzie otvorenosti, v súlade s predpokladom sa potvrdil vzt'ah s intelektuálnovedeckými záujmami, ale nepotvrdil sa predpokladaný vzt’ah s umelecko-jazykovými záujmami. Vysvetlenie by opät' mohol ponúknut' výskum Hudákovej a Sollára (2018), kde sa nepreukázal vzt’ah umelecko-jazykových záujmov a otvorenosti na úrovni tejto všeobecnej dimenzie, ale na úrovni faciet, kde dve facety otvorenosti (otvorenost' voči estetike, otvorenost' voči pocitom) korelovali s umelecko-jazykovými záujmami a ostatné facety nie. Dokonca v prípade facety otvorenosti voči estetike išlo o jeden z najsilnejších zistených vzt'ahov (Hudáková, Sollár, 2018). Uvedené môže poukazovat' na to, že pri vzt’ahu otvorenosti s umelecko-jazykovými záujmami záleží práve na konkrétnych facetách otvorenosti. Pri otvorenosti sa nám prejavil aj jeden neočakávaný vzt'ah, a to vzt'ah s podnikatel'skými záujmami. Podnikatel'ské záujmy sú tie, ktoré dominujú u manažérov v našom výskume, preto si myslíme, že vzt’ah tohto záujmového typu a otvorenosti by mohol byt' práve špecifikom danej výskumnej vzorky.

Ďalšou skúmanou osobnostnou dimenziou bola svedomitost', u ktorej sme predpokladali vzt'ah s organizačno-riadiacimi záujmami. Tento vzt'ah sa nepotvrdil, čo je v protiklade s predošlými výskumami (Gottfredson, Jones, Holland, 1993; Larson, Rottinghaus, Borgen, 2002; Bergmann, Eder, 2011; Hudáková, Sollár, 2016; Hudáková, Sollár, 2018). Svedomití jednotlivci sú ciel'avedomí, spol'ahliví, so silnou vôlou (Ruisel, Halama, 2007). Tieto vlastnosti môžu byt' dôležité pre manažérsku pozíciu. Podl'a Jonesa, Georga a Hilla (1998) je dokonca potrebné, aby sa manažér nepohyboval na spodnej hranici rozmedzia pre svedomitost'. Uvažujeme, že manažéri môžu byt' svedomití, no nemusia zároveň inklinovat' k organizačno-riadiacim záujmom. Ich svedomitost’ sa môže prejavovat' vzhl'adom na iné činnosti, než tie, ktoré sú typické pre organizačno-riadiace záujmy (napr. narábanie s údajmi, dodržiavanie pravidiel a pod.).

Naše výsledky poukazujú na prívetivost’ako na osobnostnú dimenziu najviac spätú s kariérovými záujmami. Prívetivost' korelovala s tromi typmi kariérových záujmov, pričom dva vzt'ahy boli stredne silné. Vzt'ah prívetivosti a sociálnych záujmov bol dokonca najsilnejší zo všetkých zistených vztahov. Uvedený vzt’ah potvrdzuje náš predpoklad a je v súlade s predošlými výskumami (Larson, Borgen, 2002; Larson, Rottinghaus, Borgen, 2002; Bergmann, Eder, 2011; Hudáková, Sollár, 2016; Hudáková, Sollár, 2018). Okrem sociálnych záujmov prívetivost' tiež korelovala pozitívne s umelecko-jazykovými a negatívne s prakticko-technickými záujmami. Tieto dva vzt’ahy sme na základe predchádzajúcich štúdií neočakávali (napr. Gottfredson, Jones, Holland, 1993; Tokar, Swanson, 1995; Larson, Borgen, 2002; Larson, Rottinghaus, Borgen, 2002; Bergmann, Eder, 2011; Hudáková, Sollár, 2018). Výsledky sú v rozpore so zisteniami (Bergmann, Eder, 2011; DeFruyt, Mervielde, 1997), ktoré naznačujú, že prakticko-technická dimenzia nie je pokrytá pät'faktorovým modelom osobnosti. Myslíme si, že aj tento výsledok môže byt' špecifický práve vzhl'adom na výskumnú vzorku manažérov, u ktorých je prakticko-technický záujmový typ zastúpený spomedzi všetkých Hollandových dimenzií najmenej.

\section{ZÁVER}

Štúdia sa zaoberala osobnost'ou a kariérovými záujmami manažérov. Najviac preferovanými záujmami u manažérov $v$ našom výskume boli podnikatel'ské záujmy, čo je v súlade s charakteristikou jednotlivcov podnikatel'ského typu, pre ktorých sú typické práve manažérske povolania (Džuka, 1999). Najmenej preferovanými boli prakticko-technické záujmy. Pri skúmaní súvislosti osobnosti a kariérových záujmov sme zistili, že tri dimenzie osobnosti (extraverzia, otvorenost' a prívetivost') sú vo vzt’ahu surčitými kariérovými záujmami. Nepotvrdila sa predpokladaná súvislost' neurotizmu s podnikatel'skými záujmami a svedomitosti s organizačnoriadiacimi záujmami. Pri nepotvrdení niektorých vzt’ahov predpokladaných na základe predošlých 
výskumov a preukázaní neočakávaných vzt’ahov by mohlo íst’ o špecifikum výskumnej vzorky manažérov. Predošlé výskumy zamerané na vzt'ah kariérových záujmov a osobnosti neboli realizované na takto špecifickej vzorke. Odporúčame preto dôkladnejšie preskúmanie súvislosti týchto konštruktov u manažérov napr. aj na úrovni faciet osobnostných dimenzií.

\section{LITERATÚRA}

Armstrong, P. I., Su, R., \& Rounds, J. (2011). Vocational interests: The road less traveled. In T. Chamorro-Premuzic, S. von Strumm, \& A. Furnham, (Eds.), Handbook of Individual Differences (608631). Oxford: Wiley-Blackwell.

Bergmann, CH., \& Eder, F. (1992). Allgemeiner Interessen-Struktur-Test/Umwelt-Struktur-Test. Retrieved from http://www.stangl-taller.at/TESTEXPERIMENT/testbspaist.html>.

Bergmann, CH., \& Eder, F. (2011). General interest structure test. Mödling: Schuhfried.

Boroš, J., Ondrišková, E., \& Živčicová, E. (1999). Psychológia. Bratislava: Iris.

Carless, S. A. (1999). Career assessment: Holland's vocational interests, personality characteristics, and abilities. Journal of Career Assessment, 7(2), 125-144.

Cejthamr, V., \& Dědina, J. (2010). Management a organizační chování (2nd ed.). Praha: Grada.

Cooper, A. J., Smillie, L. D., \& Corr, P. J. (2010). A confirmatory factor analysis of the Mini-IPIP fivefactor model personality scale. Personality and Individual Differences, 48(5), 688-691.

Costa, P. T., \& McCrae, R. R. (1992). NEO-PI-R professional manual. Odessa, FL: Psychological Assessment Resources.

Costa, P. T., McCrae, R. R., \& Holland, J. L. (1984). Personality and vocational interests in an adult sample. Journal of Applied psychology, 69 (3), 390-400.

DeFruyt, F., \& Mervielde, I. (1997). The five-factor model of personality and Holland's RIASEC interest types. Personality and Individual Differences, 23(1), 87-103.

Donnellan, M. B., Oswald, F. L., Baird, B. M., \& Lucas, R. E. (2006). The mini-IPIP scales: tiny-yeteffective measures of the Big Five factors of personality. Psychological assessment, 18(2), 192-203.

Džuka, J. (1999). Konštruktová validita dotazníka štruktúry všeobecných záujmov (DŠVZ). Československá psychologie, 43(2), 143-154.

Goldberg, L. R. (1999). A broad-bandwidth, public domain, personality inventory measuring the lower-level facets of several five-factor models. Personality psychology in Europe, 7(1), 7-28.

Gottfredson, G. D., \& Johnstun, M. L. (2009). John Holland's Contributions: A Theory-Ridden Approach to Career Assistance. The career development quarterly, 58(2), 99-107.

Gottfredson, G. D., Jones, E. M., \& Holland, J. L. (1993). Personality and vocational interests: The relation of Holland's six interest dimensions to five robust dimensions of personality. Journal of Counseling Psychology, 40 (4), 518-524.

Hogan, R., \& Blake, R. (1999) John Holland's vocational typology and personality theory. Journal of Vocational Behavior, 55(1), 41-56.

Holland, J. L. (1973). Making vocational choices: A theory of careers. Englewood Cliffs, NJ: PrenticeHall. 
Holland, J. L. (1979). The Self-Directed Search. Professional Manual. Palo Alto: Consulting Psychology Press.

Holland, J. L. (1997). Making vocational choices: A theory of vocational personalities and work environments. Odessa, FL: Psychological Assessment Resources.

Holland, J. L., Johnstun, J. A. \& Asama, N. F. (1994). More evidence for the relationship between Holland's personality types and personality variables. Journal of Career Assessment, 2(4), 331-340.

Hřebíčková, M. (2011). Pětifaktorový model v psychologii osobnosti: Přístupy, diagnostika, uplatnění. Praha: Grada.

Hudáková, M., \& Sollár, T. (2016). Validita revidovanej verzie testu na zist'ovanie štruktúry všeobecných záujmov (AISTR). In E. Sollárová, \& T. Sollár (Eds.), Psychológia práce a organizácie 2016: Zborník z medzinárodnej konferencie (1.st ed., pp.76-87). Nitra: Univerzita Konštantína Filozofa v Nitre.

Hudáková, M., \& Sollár, T. (2018). Vzt’ah kariérových záujmov a štruktúry osobnosti. In M. Blatný, M. Jelínek, P. Květon, \& D. Vobořil (Eds.), Sociální procesy a osobnost 2017: sborník příspěvků, Brno 18.-20.2017 (1.st ed., pp. 123-128). Brno: Psychologický ústav AV ČR.

John, O. P., \& Srivastava, S. (1999). The big-five trait taxonomy: History, measurement and theoretical perspectives. California: Department of psychology.

Jones, G., George, J., \& Hill, J. (1998). Contemporary Management. Boston: McGraw-Hill.

Judge, T. A., Bono, J. E., Ilies, R., \& Gerhardt, M. W. (2002). Personality and leadership: a qualitative and quantitative review. Journal of applied psychology, 87(4), 765-780.

Larson, L. M., \& Borgen, F. H. (2002). Convergence of Vocational Interests and Personality: Examples in an Adolescent Gifted Sample. Journal o Vocational Behavior, 60(1), 91-112.

Larson, L. M., Rottinghaus, P. J., \& Borgen, F.H. (2002). Meta-analyses of Big Six Interests and Big Five Personality Factors. Journal of Vocational Behavior, 61(2), 217-239.

Lepeňová, D., \& Hargašová, M. (2012). Kariéra v meniacom sa svete. Bratislava: Metodickopedagogické centrum.

McCrae, R. R., \& John, O. P. (1992). An introduction to the five-factor model and its applications. Journal of Personality, 60(2), 175-215.

Mezera, A. (2005). Hollandova teorie profesního vývoje: př́ručka. Retrieved from http://vychovavzdelavani.cz/download/holland mezera.pdf >

Míka, V. T. (2006). Základy manažmentu: Virtuálne skriptá. Retrieved from http://fsi.uniza.sk/kkm/files/publikacie/mika ma.html.

Mount, M. K., Barrick, M. R., Scullen, S. M., \& Rounds, J. (2005). Higher-order dimensions of the big five personality traits and the big six vocational interest types. Personnel psychology, 58(2), 447478.

Pässler, K., Beinicke, A., \& Hell, B. (2015). Interests and intelligence: A meta-analysis. Intelligence, 50, 30-51.

Rounds, J., \& Su, R. (2014). The nature and power of interests. Current Directions in Psychological Science, 23(2), 98-103.

Ruisel, I. (2008). Osobnost'a poznávanie. Bratislava: Ikar. 
Ruisel, I. \& Halama, P. (2007). NEO pät'faktorový osobnostný inventár. Praha: Testcentrum.

Schinka, J.A., Dye, D.A. \& Curtiss, G. (1997). Correspondence between five-factor and RIASEC models of personality. Journal of personality assessment, 68(2), 355-368.

Stýblo, J. (1993). Personální management. Praha: Grada.

Tokar, D. M. \& Swanson, J. L. (1995). Evaluation of the correspondence between Holland's vocational personality typology and five-factor model of personality. Journal of vocational behavior, 46(1), 89-108.

Tokar, D. M., Vaux, A. \& Swanson, J. L. (1995). Dimensions relating Holland's vocational personality typology and the five-factor model. Journal of Career Assessment, 3(1), 57-74.

Veber, J. et al. (2007). Management: základy, prosperita, globalizace. Praha: Management Press.

Vendel, Š. (2008). Kariérní poradenství. Praha: Grada Publishing.

\title{
RELATIONSHIP BETWEEN PERSONALITY AND VOCATIONAL INTERESTS IN MANAGERS
}

\begin{abstract}
The aim of the study was examination of relationship between Holland's theory of vocational interests (1997) and five-factor model of personality (Costa, McCrae, 1992) in managers. The research sample consisted of 79 managers (47 men, 32 women) with average age $\mathrm{M}=43.01$ ( $\mathrm{SD}=9.25$ ). For measuring the five-factor model of personality we used Mini-IPIP (Mini-International Personality Item Pool). Vocational interests were measured by General Interest Structure Test (AIST). We found out that three personality dimensions are correlated with vocational interests. Some relationships between vocational interests and personality dimensions can be specific in managers.
\end{abstract}

Keywords: vocational interests, personality, managers

Grantová podpora:

Príspevok vznikol ako súčast' riešenia grantových projektov APVV-0540-12: Psychometrická kvalita psychodiagnostických nástrojov v kariérovom poradenstve a UGA IX/3/2019: Skúmanie kariérových záujmov a ich vzt’ahu k osobnostným a demografickým faktorom. 